\title{
Leadership and Job Satisfaction in the Healthcare Sector: An Exploratory Study in Lebanon
}

\author{
Said Hussein ${ }^{1} \&$ Inaya Wahidi $^{1}$ \\ ${ }^{1}$ Faculty of Economics and Business Administration, Lebanese University, Hadath, Lebanon \\ Correspondence: Inaya Wahidi, Faculty of Economics and Business Administration, Lebanese University, \\ Hadath, Lebanon.
}

Received: May 2, 2018

Accepted: May 19, 2018

Online Published: June 5, 2018

doi:10.5539/ibr.v11n7p46

URL: https://doi.org/10.5539/ibr.v11n7p46

\begin{abstract}
More and more, healthcare institutions work to ameliorate the relation supervisor/supervised. In hospitals, transformational leadership proved to influence employee's motivation and satisfaction (Spinelli, 2006, p.20) thus the hospital's services. To our knowledge, there is no study conducted on the administrative employees in the healthcare sector in Lebanon that constitute our sample. There is only one study conducted on nurses by El-Jardali et al., (2008) in 69 hospitals in this country. Given this situation, we how can describe the relationship between transformational leadership and employee's job satisfaction in hospitals? Data processing of a questionnaire administered to 455 employees of 28 over 125 hospitals in Lebanon shows that there is no significant relationship between the employee's job satisfaction and these two transformational leadership components: leader's idealized influence and intellectual stimulation. While we found a correlation between employee's job satisfaction and two other components: inspirational motivation (Training; projects monitoring) and individualized consideration (Active listening to employee's work issues).
\end{abstract}

Keywords: employee's job satisfaction, leadership, Lebanese healthcare sector, transformational leadership

\section{Introduction}

More and more, leadership styles importance is highlighted in the literature to achieve the firm goals (Ellis and Hartley, 2009, p. 668) and to enhance organizational and employee's performance (Adams and Bond, 2000; Al-Hussami, 2008; Larsson and Vinberg, 2010). The literature highlights the importance of the two leadership styles to motivate employees and to boost their performance: transactional and transformational. Transactional leaders use a lot of stimulants to incite their employees and to enhance their performance or in another word, everything is ok in the short term. Transformational leaders use incentives also to boost their employee's performance but they try to change their employees for the better on the personal and professional level. Transformational leadership reduces employee's turnover and absenteeism rates (Bass and Avolio, 1990). In the healthcare sector especially in hospitals, the transformational leadership style is dominant. Spinelli (2006) highlighted the efficiency and the success of the application of transformational leadership in hospitals according to the outcomes. Many studies showed that employees are dissatisfied for several reasons in Lebanon. For example, regarding the bank sector, an exploratory study (Crossman and Abou Zaki, 2003) conducted on two hundred two employees in Lebanon shows that «job satisfaction is not independent in all job facets». Results show that female employees in the Lebanese bank sector are "less satisfied with all facets except pay» especially «those with lower educational qualifications».

Regarding hospitals in Lebanon, a study conducted on 421 registered nurses applying many dimensions of satisfaction shows «a high level of personal satisfaction, but nurses were most dissatisfied with salary and lack of prospects for promotion» (Yaktin and al., 2003). To our knowledge, there is no study conducted on the administrative employees in the healthcare sector in Lebanon that constitute our sample. There is only one study conducted on nurses by El-Jardali et al., (2008) in 69 hospitals in this country. In Lebanese hospitals, employees suffer from «lack of managerial support» that decreases their satisfaction and motivation (El-Jardali et al., 2008). Given this situation, we how can describe the relationship between transformational leadership and employee's job satisfaction in hospitals? 
To reply to this question, we will present a brief literature review with our research objectives then the methodology and the results. These latter will be discussed while presenting the limitations of this work, before presenting the conclusion.

\section{Literature Review and Research Objectives}

Now, we will debate the importance of examining transformational leadership and employee's job satisfaction (1.1) and the influence of this style on employee's job satisfaction in the Lebanese healthcare strip (1.2).

\subsection{The Importance of Examining Transformational Leadership and Employee's Job Satisfaction}

Successful leaders must meet effective leading characteristics to improve job satisfaction. Innovative, creative and visionary are considered as key predictors of the best leaders (Yukl, 2010; Mullins, 2010).Reduced employee's turnover rates, high retention levels, and high satisfaction can be maintained through effective leader characteristics especially via transformational leader (Sofarelli and Brown, 1998).

The literature highlights the importance of transformational leadership more than the transactional one. It highlights the dominance of transformational leadership and its impact on employee's job satisfaction (Burns, 1978; Bass, 1985; Yukl and Fleet, 1992; Bass and Avolio, 1994; Conger, 1999; Fernandes and Awamleh, 2004; Burke et al., 2006; Jack and Rudnick, 2007; Glynn and DeJordy, 2010 ; Diaz-Saenz, 2011; Aryee et al., 2012; Tuand Lu, 2013; To,Tse, and Ashkanasy, 2015). Effective and efficient leaders reflect employee's satisfaction, motivation, and commitment (Erkutlu, 2008). Transformational leaders lead their subordinates toward innovation, self-change, satisfaction, and commitment through supporting and building a strong relationship with them (Curtis and O'connell, 2011; Mullins, 2010). According to Golden (2012), transformational leader enhances employee's job satisfaction and performance through listening, data sharing, persuading, discussing and supporting each other. Innovation encouragement by transformational leaders should be highlighted to reach firm's and individuals' goals (Näswall et al., 2015).

\subsection{Transformational Leadership and Employee's Job Satisfaction Importance in the Lebanese Healthcare Strip}

Regarding the Lebanese context, organizations suffer from high costs, low performance, low profitability, low employee's retention rates and high turnover rates because of the low priority is given to the employee satisfaction (Yahchouchi, 2009). Despite this situation, leadership style tend to be more transformational in Lebanon but with a special focus on the Lebanese collectivistic culture and religion. According to Akl et al., (2007), Lebanese hospital's employees are dissatisfied and intent to leave their job. To our knowledge, as mentioned previously, there is no study conducted on the administrative employees. In Lebanon, there is only one study conducted on nurses (El-Jardali et al., 2009). He conducted his study because he found a shortage of data regarding the characteristics and the real number of nurses. The research was conducted in 69 Lebanese hospitals on 1793 nurses with a high response rate «76.17\%». What attracts the attention is that Lebanese hospitals suffer from paucity in nurses (El-Jardali et al., 2009). So, are they few or tend to leave their job? According to the results, they have the intention to leave their job. Results show high turnover rates, absenteeism, low satisfaction with the degree of participation, lack of appraisal and managerial support, inflexible working hours, frustrating control, workload and hard tasks, low incomes and insufficient rewards. Also, they prefer to migrate to Gulf countries where they can find a better opportunity in a period of one to three years of executing their job. All of these factors reflect nurse's dissatisfaction and de-motivating environment. In the healthcare sector, Laschinger and Havens (1996) highlight nurse's participation and satisfaction to increase their productivity and to enhance patient care. Remember that we are talking about a sensitive sector where the motivation of nurses and administrative employees and their behavior with patients influences it psychologically. Here lies the importance of transformational leadership in Lebanese hospitals.

So, what about administrative employees' job satisfaction determinants through studying the impact of transformational leadership style?

In the following, we will represent four determinants of transformational leadership and its impact on job satisfaction adapted from many authors (Choi Sang et al., 2014, p.121):

Idealized Influence (Reach goals; objectives definition; Actions development; optimistic communication; employee's respect; sharing ideas); Intellectual Stimulation (New ideas; Delay intervention; decision making ethical consequences ;Challenge stimulation; Challenge management; New perspectives support);Inspirational motivation (Employee importance; Optimism influence; orientation toward opportunity; Frequent assistance; Training; Trust feeling; Projects monitoring) ; Individualized Consideration (employee Respect; Group support; Listening support; Incessant Appraisal; Individual interests; Individual judgment). 
From the previous determinants, we will present our hypothesis as follows:

H1: Employee job satisfaction is affected by "Idealized influence".

H2: Employee job satisfaction is affected by "Intellectual stimulation".

H3: Employee job satisfaction is affected by "Inspirational motivation".

H4: Employee job satisfaction is affected by "Individual consideration".

These tested hypotheses will be rejected or accepted according to our results that it will be presented in part 2 .

\section{Methodology}

Now, we will present the research nature, the sample and data collection method, the variables and finally the data processing technique.

\subsection{The Research Nature}

Our academic work is more informative because it is related to a particular context (Paturel, 2004). The obtained qualitative information is treated as quantitative. Our exploratory study covered a small sample regarding the original population. The research is still exploratory and limited on a quasi-ignored subject in Lebanon and it is a kind of a debate research to be extended to clarify many hidden points later. The study looks at presenting information (got from administrative employees) on leadership and employee's job satisfaction in Lebanese hospitals.

\subsection{Sample and Data Collection}

This research started in April 2017 by contacting the companies by telephone to administer a face to face questionnaire to hospitals administrative employees on the issue of leadership and job satisfaction. According to the syndicate of hospitals in Lebanon, there are 125 hospitals. We contacted the 125 hospitals and we had a return of 28 of them, a response rate of $22.4 \%$ (28/125). The remaining 97 refused the administration of the questionnaire. For some, their telephone line was so busy all the time. In this case, we can say that the response rates are not bad for an exploratory study with these faced problems. We administrated 455 questionnaire quasi-equals regarding the number from each hospital. Our work was spread out from April 2017 to February 2018 and the duration of the questionnaire varied from 15 to 20 minutes per employee.

Concerning the questionnaire, we asked for information such as the average age of the majority of the employees (from $<20$ years to $>50$ years) and their gender, educational level, educational domain, professional experience, years of experience in the current hospital and their current working department.

Finally, we asked questions related to four independent meta-variables regarding leadership influence (idealized influence; intellectual stimulation; inspirational motivation; individual consideration) and one dependent variable (Job satisfaction). A question on the job satisfaction factors was asked.

\subsection{Research Variables}

Inspired by the modelization of Choi Sang et al. (2014), we have establish the independent variables. We have four meta-independent variables related to the impact of transformational leadership on job satisfaction. Job satisfaction is our dependent variable. We have used the Likert scale at five levels with 1- Strongly disagree; 2disagree; 3- neutral; 4- agree; 5-strongly agree. We have planned a number of independent variables to each meta- independent variable as follows:

\section{Idealized Influence}

- Firm goals are achieved by sharing a common vision with your manager.

- Firm vision and objectives are well defined.

- $\quad$ Firm vision is well achieved by your manager.

- There is an optimistic manager's communication regarding the future of the organization.

- You are treated with a sense of confidence and respect by your manager.

- Your manager share ideas with you.

\section{Intellectual Stimulation}

- Your manager changes your way of thinking and resolving problems optimally.

- Your manager gives you enough time to solve problems before interfering.

- Your manager aware you about the ethical consequences of your decision making participation. 
- You agree with your manager regarding his morals and ideals.

- Your manager is a person that challenge the old processes

- Your manager has new perspectives regarding your firm issues.

\section{Inspirational motivation}

- Your manager makes you feel that you are very important to your organization

- Your manager diffuses positive vibes to achieve your goals.

- According to your manager, you have to catch the opportunity from your environment

- Your manager is a good listener and assistant

- You are learning a lot from your manager through providing training sessions

- Your capabilities are well recognized by your manager

- Organizational future plans are well monitored by your manager

\section{Individualized Consideration}

- You fell that you are well respected by your organization

- You feel that you are a harmonious group in the organization.

- Your manager is a good listener to your work issues

- Your manager is a good appraisal of your original work

- Your manager gives importance to your values and benefits

- Your manager does an individual rating in a teamwork

Concerning our dependent variable (Job satisfaction) our asked question is the following:

"Does the interchange with your manager have a positive impact on your job satisfaction?"

A question was asked about the job satisfaction factors affected by the managers regarding the following: providing training sessions; achievement appreciation; respect; motivation through incentives; employee's trust; creating a secure environment; meeting employee's expectations and individual effort appraisal.

\subsection{Data Processing Techniques}

We used SPSS 17 software to obtain the frequency tables and to use the principal components analysis technique (PCA) with a "varimax" rotation to reduce the number of variables by decreasing the amount of information through grouping the various items measured by a small number of factors. This technique enables the testing of the validity of the scales because it includes the KMO (Kaiser-Meyer-Olkin) test, which must be greater than 0.5 to allow the execution of the PCA reflecting the interrelation of the variables. The Bartlett test is always accompanied by the PCA test. Then, the Cronbach Alpha test was executed. It indicates the homogeneity and the reliability of the scale. Cronbach Alpha significance is 0.60 (Evrard et al., 1997, Igalens and Roussel, 1998). Factors with a low contribution $(<0.50)$ on the same factor are eliminated. When all these previous cited tests were significant, we executed multiple regressions to test the relationship between the dependent variable "Job satisfaction" and the independent variables previously cited. Regarding multiple regressions, the sig of the ANOVA test in the regression must be $<0.05$.

\section{Results and Analysis}

Table 1 below shows employees' general information. Employees represent More male than female $(55.4 \%$ Male and $44.6 \%$ Female). Their age varies between $<20$ years old $(2 \%)$ and $>50$ years old $(3.7 \%)$. Less of the half is specialized in business administration (45.7\%). More than the half has a professional experience between 5 and 10 years $(16.7 \%)$ and more than 10 years $(35.9 \%)$. Only $10.3 \%$ has less than one year of experience in the current hospital. Hospital locations of employees are quasi-equal in Beirut, North Metn and Baabda, Keserouan and Jbeil, Chouf and Aley, North and South.

Table 2 below digests the results of the PCA, the Cronbach alpha and the multiple regressions on employees' responses on leadership influence (independent meta-variables) and job satisfaction (dependent variable) in Lebanese hospitals. The results show the validity and reliability of the scale regarding the determinants of employee's job satisfaction. The results of the regression reveal two determinants of leadership related to the inspirational motivation and its influence on employee's job satisfaction: continuous training and projects monitoring. Concerning the individual consideration meta-variable, the results of the regression reveal one 
determinant of leadership and its influence on employee's job satisfaction: the leader's listening support.

Table 1. Employees general information

\begin{tabular}{|c|c|c|c|c|c|c|c|}
\hline $\begin{array}{l}\begin{array}{l}\text { Number } \\
\text { of } \\
\text { employe } \\
\text { es / } \\
\text { General } \\
\text { informat } \\
\text { ion }\end{array} \\
\end{array}$ & $\begin{array}{l}\text { Gende } \\
\mathrm{r}\end{array}$ & Age & Educational level & $\begin{array}{l}\text { Education } \\
\text { al domain }\end{array}$ & $\begin{array}{l}\text { Professional } \\
\text { experience }\end{array}$ & $\begin{array}{l}\text { Years of } \\
\text { experience in } \\
\text { the current } \\
\text { hospital }\end{array}$ & $\begin{array}{l}\text { Hospital } \\
\text { location } \\
\text { employees }\end{array}$ \\
\hline$(\mathrm{N}=455)$ & $\begin{array}{l}\text { Male= } \\
252 \\
(55.4 \% \\
) \\
\text { Female } \\
=203 \\
(44.6 \% \\
)\end{array}$ & $\begin{array}{l}<20 \\
\text { years } \\
\text { old }(2 \\
\%) ; \\
\mathbf{2 0 - 2 5} \\
(19.8 \\
\%) ; \\
26-30 \\
(39.1 \\
\%) ; \\
31-40 \\
(26.8 \\
\%) ; \\
\mathbf{4 1 - 5 0} \\
(8.6 \%) \\
; \quad> \\
\mathbf{5 0}(3.7 \\
\%)\end{array}$ & $\begin{array}{l}\text { Bachelor's degree } \\
\text { (53.8\%);Master's } \\
\text { degree } \\
(34.1 \% \text {;Doctoral } \\
\text { degree (2\%) } \\
\text { others }(10.1 \%)\end{array}$ & $\begin{array}{l}\text { Business } \\
\text { administra } \\
\text { tion } \\
(45.7 \%) ; \\
\text { Others } \\
(54.3 \%)\end{array}$ & 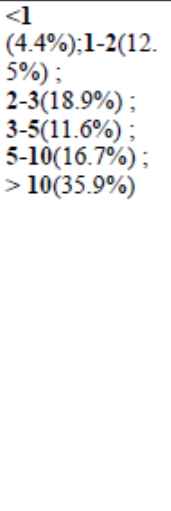 & $\begin{array}{l}<\mathbf{1} \\
(10.3 \%) ; \mathbf{1 - 2}(13 . \\
6 \%) ; \\
\mathbf{2 - 3}(30.8 \%) ; \\
\mathbf{3 - 5}(9.3 \%) ;>\mathbf{5}( \\
36 \%) .\end{array}$ & $\begin{array}{l}\text { Beirut } \\
(16.5 \%) ; \\
\text { NorthMetn } \\
\text { and Baabda } \\
(17.6 \%) ; \text { Keser } \\
\text { ouan and Jbeil } \\
(13.2 \%) ; \\
\text { Chouf and } \\
\text { Aley }(13.2 \%) ; \\
\text { Bekaa(13.2\%); } \\
\text { North(13.2\%); } \\
\text { South }(13.2 \%) \text {. }\end{array}$ \\
\hline
\end{tabular}

Source: Authors.

Table 2. PCA, Cronbach Alpha and multiple regressions on employees' responses on leadership influence (independent meta-variables) and job satisfaction (dependent variable) in Lebanese hospitals (Varimax rotation)

\begin{tabular}{|c|c|c|c|c|c|c|}
\hline $\begin{array}{l}\text { Meta- } \\
\text { independent } \\
\text { variables }\end{array}$ & $\begin{array}{l}\text { KMOO (Scale } \\
\text { Validity test) }\end{array}$ & $\begin{array}{l}\text { Bartlett } \\
\text { (Scale } \\
\text { Validity } \\
\text { test) }\end{array}$ & $\begin{array}{l}\text { Cronbach } \\
\text { a } \\
\text { (Scale } \\
\text { Reliability } \\
\text { test) }\end{array}$ & Variance \% & Anova test & $\begin{array}{l}\text { Multiple } \\
\text { regression }\end{array}$ \\
\hline $\begin{array}{l}\text { 1-Idealized } \\
\text { infuence }\end{array}$ & $\begin{array}{l}0.660 \\
>0.5 \\
\text { The variables are } \\
\text { inter-correlated. }\end{array}$ & $\begin{array}{l}0.000<0.5 \\
\text { variables } \\
\text { are } \\
\text { correlated }\end{array}$ & $\begin{array}{l}0.492< \\
0.60 \\
\text { Only } 49.2 \% \\
\text { of the } \\
\text { scores are } \\
\text { true, so the } \\
\text { variables } \\
\text { are not well } \\
\text { inter- } \\
\text { correlated } \\
\text { and the } \\
\text { regression } \\
\text { cannot be } \\
\text { continue. }\end{array}$ & & & \\
\hline $\begin{array}{l}\text { 2- } \\
\text { Intellectual } \\
\text { stimulation }\end{array}$ & $\begin{array}{l}0.579 \\
>0.5 \\
\text { The variables are } \\
\text { inter-conrelated. }\end{array}$ & $\begin{array}{l}0.000-0.5 \\
\text { variables } \\
\text { are } \\
\text { correlated }\end{array}$ & $\begin{array}{l}0.393=0.60 \\
\text { So, the } \\
\text { variables } \\
\text { are not } \\
\text { inter- } \\
\text { correlated. }\end{array}$ & & & \\
\hline $\begin{array}{l}\text { 3- } \\
\text { Inspirationa } \\
1 \text { motivation }\end{array}$ & $\begin{array}{l}0.690 \\
>0.5 \\
\text { The variables are } \\
\text { inter-correlated. }\end{array}$ & $\begin{array}{l}0.000=0.5 \\
\text { variables } \\
\text { are } \\
\text { correlated }\end{array}$ & $\begin{array}{l}0.614 \\
0.60 \\
\text { So, the } \\
\text { variables } \\
\text { are well } \\
\text { inter- } \\
\text { conrelated. }\end{array}$ & $\begin{array}{l}30.615 \\
16.295 \\
\text { The first dimension } \\
\text { extracted explains } \\
30.615 \% \text { of the } \\
\text { variance. The } \\
\text { conrelated factors ( } \\
0.50 \text { ) related to this } \\
\text { dimension are:(1) } \\
\text { orientation toward } \\
\text { opportunity } \\
\text {; (2) Training } \\
\text { (3) Trust feeling } \\
\text { and (4) Projects } \\
\text { monitoring }\end{array}$ & $\begin{array}{l}0.000<0.05 \\
\text { significant }\end{array}$ & $\begin{array}{l}\text { Training: } \\
\text { Sig= } 0.046< \\
0.05 \\
\text { significant } \\
\text { Projects } \\
\text { monitoring } \\
\text { Sig= } 0.000< \\
0.05 \quad \\
\text { significant }\end{array}$ \\
\hline $\begin{array}{l}\text { - } \\
\text { Individual } \\
\text { consideratio } \\
\mathrm{n}\end{array}$ & $\begin{array}{l}0.641 \\
>0.5 \\
\text { The variables are } \\
\text { inter-correlated. }\end{array}$ & $\begin{array}{l}0.000=0.5 \\
\text { The } \\
\text { variables } \\
\text { are } \\
\text { correlated }\end{array}$ & $\begin{array}{l}0.604 \text { ' } \\
0.60 \\
\text { So, the } \\
\text { variables } \\
\text { are well } \\
\text { interrelated. }\end{array}$ & $\begin{array}{l}33.840 \\
21.226 \\
\text { The first dimension } \\
\text { extracted explains } \\
33.840 \% \text { of the } \\
\text { variance. The } \\
\text { correlated factors ( } \\
0.50) \text { related to this } \\
\text { dimension are:(1) } \\
\text { employee } \\
\text { Respect;(2) Group } \\
\text { support; and (3) } \\
\text { Listening support } \\
\text { and (4)Incessant } \\
\text { Appraisal. }\end{array}$ & $\begin{array}{l}0.000<0.05 \\
\text { significant }\end{array}$ & $\begin{array}{l}\text { Listening } \\
\text { support: } \\
\text { Sig= } \quad 0.001< \\
0.05 \\
\text { significant }\end{array}$ \\
\hline
\end{tabular}


Source: Authors.

Given these results, it appears that the "Idealized influence" and "Intellectual stimulation" in transformational leadership may be absent in the Lebanese hospitals because the scale is not valid or reliable.

Table 3 below shows employees' responses to job satisfaction factors. Most of the employees seem to agree on motivating job satisfaction factors and with one none motivating one (stress and workload with $48.1 \%$ of respondent's answers).

Table 3. Employee's responses on job satisfaction factors (in percentage)

\begin{tabular}{|c|c|c|c|c|c|}
\hline $\begin{array}{l}\text { Job satisfaction factors/ Responses } \\
(N=455)\end{array}$ & Strongly disagree & Disagree & Neutral & Agree & Strongly agree \\
\hline Training sessions & 1.1 & 3.5 & 13.4 & 51.4 & 30.5 \\
\hline Appreciation feeling & 1.1 & 8.8 & 20.4 & 48.6 & 21.1 \\
\hline Respect feeling & 1.3 & 2.9 & 30.3 & 45.7 & 19.8 \\
\hline Incentives & 2.9 & 14.3 & 24.6 & 39.3 & 18.9 \\
\hline Trustful relationship with the manager & 1.3 & 6.8 & 18.7 & 55.2 & 18 \\
\hline Responsibility feeling & 0 & 6.4 & 26.8 & 47.9 & 18.9 \\
\hline Realized expectations & 0 & 4.4 & 35.6 & 47.5 & 12.5 \\
\hline Appraisal & 2.2 & 2 & 30.3 & 44.2 & 21.3 \\
\hline Self-problem solving feeling & 1.1 & 7.5 & 33 & 47.9 & 10.5 \\
\hline Clear strategies explanation & 0 & 5.1 & 19.1 & 54.5 & 21.3 \\
\hline Close employees supervision & 8.1 & 9.2 & 34.3 & 42.4 & 5.9 \\
\hline Stress and workload & 2.2 & 9.9 & 27.7 & 48.1 & 12.1 \\
\hline Employee's participation in decision making & 1.3 & 15.8 & 20.4 & 44.6 & 17.8 \\
\hline Having a flexible leader & 0 & 8.4 & 15.2 & 45.1 & 31.4 \\
\hline Civilized problems treatment & 1.1 & 5.3 & 26.6 & 43.5 & 23 \\
\hline Self-development strategy encouragement & 0.2 & 12.3 & 19.1 & 45.1 & 23.3 \\
\hline Continuous feedback from managers & 1.1 & 5.3 & 29.5 & 43.7 & 20.4 \\
\hline Flexible working hours & 2.2 & 5.7 & 31.9 & 35.8 & 24.4 \\
\hline
\end{tabular}

Source: Authors.

\section{Discussion and Limitations}

Before presenting our results, we will present the first modelization of leadership impact on administrative employee's job satisfaction in Lebanese hospitals.

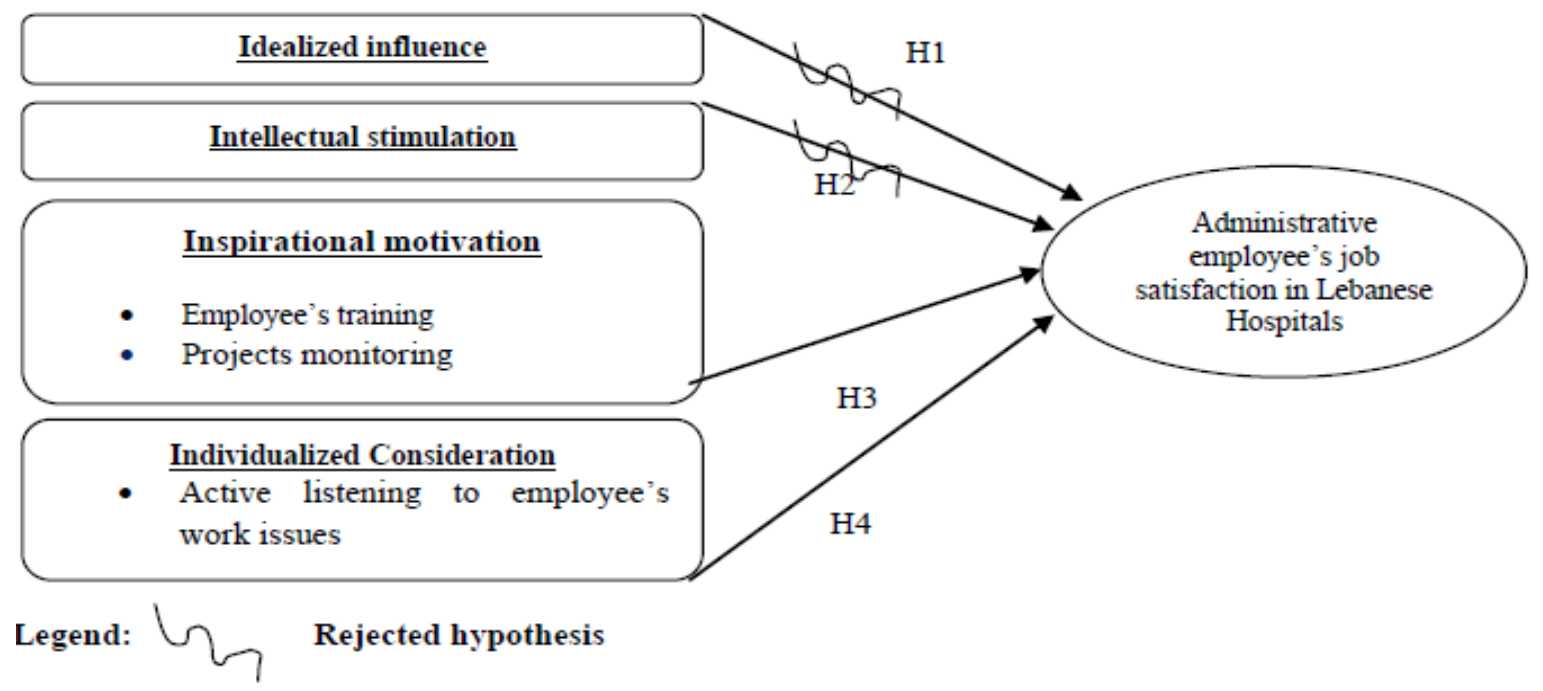

Figure 1. Towards the first modeling of leadership impact on administrative employee's job satisfaction in

Lebanese hospitals

Source: Authors

Note that our results have examined the topic of leadership influence on administrative employee's job satisfaction in Lebanese hospitals for the first time, to our knowledge, even though the study is conducted only on nurses (El-Jardali et al., 2009).

Practically, we will present recommendations to the Leaders of Lebanese hospitals to better manage administrative employee's problems. According to our results, we will present some advice to leaders. In general, 
respondents showed relatively high job satisfaction regarding their relationship with their managers. According to the literature, high satisfaction has a positive impact on firms and employees and on both performances. It leads to decreased employee's turnover rates and high commitment and motivation. Regarding the "Idealized influence" and the "Intellectual stimulation" dimensions of transformational leadership, results seem to show that leaders play no role! Concerning the "Idealized influence" leaders should strongly focus on the "innovative" side of their employees through building a strong relationship with them by sharing a common vision and ideas with them, defining clear objectives and vision, being optimistic, being respectful regarding employees capacities. Concerning the "Intellectual stimulation" leaders should strongly focus on employee's importance through their decision making participation, listening and assistance to resolve their professional problems. Moreover, results seem to show existing but weak "inspirational motivation" and "Individualized consideration". Concerning the "Inspirational motivation", transformational leadership in Lebanese hospitals seems to focus on providing training sessions and elaborating future plans with their employees. Leaders forgot a lot of things and must be more focus on how to make feeling their employees that they are very important, to diffuse positive vibes, to catch the opportunity, to listen and to recognize employee's capabilities. Concerning the "Idealized consideration", it seems that they are focused on how to be a good employee's listener only. Also, they forgot a lot of things and they must pay attention more to the importance of employee's respect, working in a harmonious group, giving appraisals, respecting values and doing individual rating in teamwork.

Concerning the theoretical level, this work confirms partially the literature linked to a number factors causing administrative employees job satisfaction in the healthcare sector in Lebanon. Inspirational motivation (Training; projects monitoring) and individualized consideration (Active listening to employee's work issues) factors that most confirms the literature in the context of healthcare sector in Lebanon are already confirmed by Choi Sang et al. (2014), the results of our work seem to challenge the literature on the factors of transformational leadership and it influence on administrative job satisfaction due to a different cultural context and a new sample composed of administrative employees in Lebanese hospitals and not nurses as the previous and only study in Lebanon conducted on nurses (El-Jardali et al., 2009).

What about the limits of this research? As a result, we could not contact CEO's who could have a different point of view than employees. These CEO's could present their views on their leadership styles and its effect on administrative employee's job satisfaction. So, this gap should be filled later on.

Regarding the methodological limits, it can be limited to the critical questions of the internal and external validity of this work. Royer and Zarlowski (2007), gives the priority to the internal validity before thinking about the generalization. We believe that our results are partially reliable given the size of the sample or, in other words, the few numbers of hospitals that accepted to fill our questionnaire. Concerning the external validity, it seems totally representative of the country because the study was carried out in all Lebanese regions (Beirut, North Metn and Baabda, Keserouan and Jbeil, Chouf and Aley, North and South), but, consequently, the results highlighted still not totally generalizable because of the small size of the sample. This exploratory research must be conducted on a larger sample to be able to generalize it and validate our research results, to be more accurate on employee's job satisfaction and to enhance the model presented. This research can be extended by studying the impact of transformational leadership on employees and organizational productivity. Finally, the majority of our participants were males (55.4\%) showing an important gender influence. But, this cannot generalize, since our sample size was small and only 28 of 125 hospitals participated. So to gain accurate results, future studies must follow a larger sample.

\section{Conclusion}

In this investigation, we have only considered the of administrative employee's point of views in Lebanese hospitals on the impact of transformational leadership on job satisfaction. Through face to face administered questionnaires, the findings above were identified.

Practically, we propose that, in terms of "idealized influence" ( rejected H 1) leaders should strongly focus on the "innovative" side of their employees through building a strong relationship with them by sharing a common vision and ideas with them, defining clear objectives and vision, being optimistic, being respectful regarding employees capacities. Concerning the "Intellectual stimulation" (rejected H2) leaders should strongly focus on employee's importance through their decision making participation, listening and assistance to resolve their professional problems.

Concerning the third hypothesis (H3) "Inspirational motivation", it was partially accepted. Transformational leaders in Lebanese hospitals seem to focus on providing training sessions and elaborating future plans with their employees but they must be more focus on how to make feeling their employees that they are very important, to 
diffuse positive vibes, to catch the opportunity, to listen and to recognize employee's capabilities. Concerning the fourth hypothesis (H4) "Idealized consideration", it was partially accepted. It seems that they are focused on how to be a good employee's listener only, but they must pay attention more to the importance of employee's respect, working in a harmonious group, giving appraisals, respecting values and doing individual rating in teamwork.

Theoretically, the results partially confirm the literature regarding some transformational leadership factors and its influence on job administrative employee's job satisfaction. Remember that only 28 hospitals out of 125 hospitals contacted participated in our study. We try to extend the literature by highlighting these factorsmentioned above - detected for the first time in the country of cedars - to our knowledge - in the sector of activity chosen (health sector: the Lebanese hospitals).

Regarding the research prospects, the view of administrative employees on the subject treated and the comparisons that can be made with the results of the Lebanese manager's views represent an important track although difficult to follow because of opacity and the Lebanese context in management research. But this issue should not be neglect if we want to better understand the phenomenon of transformational leadership impact on administrative employee's job satisfaction in order to increase the performance and productivity of these employees.

Finally, we notice that the majority of our participants were males (55.4\%) showing a possible critical influence of gender. Furthermore, we limited our study to the health sector. Further research could be extended to other sectors to make interesting comparisons on this subject to improve employees and firm's performance and productivity.

\section{References}

Adams, A., \& Bond, S. (2000). Hospital nurses' Job satisfaction, individual and organizational characteristics. Journal of Advanced Nursing, 32(3), 536-543. https://doi.org/10.1046/j.1365-2648.2000.01513.x

Akl, E. A., Maroun, N., Major, S., Chahoud, B., \& Schu“ nemann, H. J. (2007). Graduates of Lebanese medical schools in the United States: an observational study of international migration of physicians. BMC Health Services Research, 7(49). https://doi.org/10.1186/1472-6963-7-49

Al-Hussami, M. (2008). A study of nurses' job satisfaction: The relationship to organizational commitment, perceived organizational support, transactional leadership, transformational leadership, and level of education. European Journal of Scientific Research, 22(2), 286-295. Retrieved from https://pdfs.semanticscholar.org/6ba5/6041f939ac4d51e14ea81929b41fd22c62b3.pdf

Aryee, S., Walumbwa, F. O., Zhou, Q., \& Hartnell, C. A. (2012). Transformational Leadership, Innovative Behavior, and Task Performance: Test of Mediation and Moderation Processes. Human Performance, 25(1), 1-25. https://doi.org/10.1080/08959285.2011.631648

Bass, B. M. (1985). Leadership and performance beyond expectations. New York: Free Press.

Bass, B. M., \& Avolio, B. J. (1994). Improving organizational effectiveness through transformational leadership. Thousand Oaks, CA: Sage.

Bass, B., \& Avolio, B. (1990). The implications of transactional and transformational leadership for individual, team, and organizational development. Research in Organizational Change \& Development, 4, 231-272.

Burke, C. S., Stagl, K. C., Klein, C., Goodwin, G. F., Salas, E., \& Halpin, S. M. (2006). What type of leadership behaviors are functional in teams? A meta-analysis. The Leadership Quarterly, 17(3), 288-307. https://doi.org/10.1016/j.leaqua.2006.02.007

Burns, J. M. (1978). Leadership. New York, NY: Harper \& Row.

Choi Sang, L., Wan Mardhia M. Y., Tan Owee k., \& Low Hock H. (2014). The Impact of Transformational Leadership Style on Job Satisfaction, World Applied Sciences Journal, 29(1), 117-124, https://www.idosi.org/wasj/wasj29(1)14/17.pdf

Conger, J. A. (1999). Charismatic and transformational leadership in organizations: An insider's perspective on these developing streams of research. The Leadership Quarterly, 10(2), 145-179. https://doi.org/10.1016/S1048-9843(99)00012-0

Crossman A., \& AbouZaki, B. (2003). Job satisfaction and employee performance of Lebanese banking staff. Journal of Managerial Psychology, 18(4), 368-376. https://doi.org/10.1108/02683940310473118

Curtis, E., \& O’Connell, R. (2011). Essential leadership skills for motivating and developing staff. Nursing Management, 18(5), 32-35. https://doi.org/10.7748/nm2011.09.18.5.32.c8672 
Diaz-Saenz, H. R. (2011). Transformational leadership. In A. Bryman, D. Collinson, K. Grint, B. Jackson \& M. Uhl-Bien (Eds.), The SAGE handbook of leadership, 299-310, Thousand Oaks, CA: Sage.

El-Jardali, F., Dumit, N., Jamal, D., \& Mouro, G. (2008). Migration out of Lebanese nurses: a questionnaire survey and secondary data analysis. International Journal of Nursing Studies, 45(10), 1490-1500. https://doi.org/10.1016/j.ijnurstu.2007.10.012

El-Jardali, F., Merhi, M., Jamal, D., Dumit, N., \& Mouro, G., (2009). Assessment of nurse retention challenges and practices in Lebanese hospitals: the perspective of nursing directors. Journal of Nursing Management, 17(4), 453-462. https://doi.org/10.1111/j.1365-2834.2009.00972.x

Ellis, J., \& Hartley, C. (2009). Managing and Coordinating Nursing Care (5th ed.) Lippincott, Williams \& Wilkins, Philadelphia, PA, 668.

Erkutlu, H. (2008). The impact of transformational leadership on organizational and leadership effectiveness: The Turkish case. Journal of Management Development, 27(7), 708-726. https://doi.org/10.1108/02621710810883616

Evrard, Y., Pras, B., \& Roux, E. (1997). Market, Etude et recherches en marketing (2 ${ }^{\text {nd }}$ ed.). Paris, Nathan.

Fernandes, C., \& Awamleh, R. (2004). The impact of transformational and transactional leadership styles on employee's satisfaction and performance: An empirical test in a multicultural environment. International Business and Economics Research Journal, 3(8), 65-76. Retrieved from http://ro.uow.edu.au/cgi/viewcontent.cgi?article=1620\&context=dubaipapers

Glynn, M. A., \& DeJordy, R. (2010). Leadership through an organizational behavior lens: A look at the last half-century of research. In N. Nohria, \& R. Khurana (Eds.), Handbook of leadership and practice, 119-158, Boston, MA: Harvard Business Press.

Golden, L. (2012). The Effects of Working Time on Productivity and Firm Performance: a research synthesis paper. International Labor Organization (ILO) Conditions of Work and Employment Series No. 33, Conditions of Work and Employment Branch. Retrieved from file:///C:/Users/toshiba/Downloads/SSRN-id2149325.pdf

Igalens, J., \& Roussel, P. (1998), Méthodes de Recherche en Gestion des Ressources Humaines, Edition Economica, 207p.

Jack, J., \& Rudnick, J. (2007). Transformational Leadership: Model Encourages Leaders to Transcend Personal Ambition. Health Progress, 88(3), 36-40. Retrieved from https://test.chausa.org/docs/default-source/health-progress/transformational-leadership-pdf.pdf?sfvrsn=0

Larsson, J., \& Vinberg, S. (2010). Leadership behaviour in successful organisations: Universal or situation-dependent? Total Quality Management \& Business Excellence, 21(3), 317-334. https://doi.org/10.1080/14783360903561779

Laschinger, H. K., \& Havens, D. S. (1996). Staff nurse work empowerment and perceived control over nursing practice: conditions for work effectiveness. The Journal of Nursing Administration, 26(9), 27-35. https://doi.org/10.1097/00005110-199609000-00007

Mullins, L. J. (2010). Management and Organizational Behavior. Pearson Education. 9th edition. Retrieved from http://www.pearsoned.co.uk/media/OnlinePreview/Mullins_9780273728610/assets/pdf/A01_MULL4087_0 9_SE_FM\%20(3).pdf

Näswall, K., Kuntz, J., Hodliffe, M., \& Malinen, S. (2015). Employee Resilience Scale (EmpRes) Measurement Properties. Resilient Organisations Research Report. Retrieved from https://www.researchgate.net/profile/Joana_Kuntz2/publication/281593901_Employee_Resilience_Scale_E mpRes_Measurement_Properties/links/55f0a97a08ae199d47c21daa/Employee-Resilience-Scale-EmpResMeasurement-Properties.pdf

Paturel, R. (2004). Les choix méthodologiques de la recherche doctorale française en entrepreneuriat ; Remise en cause partielle d'idées préconçues. Revue de l'Entrepreneuriat, 3(1), 47-65. https://doi.org/10.3917/entre.031.0047

Royer, I., \& Zarlowski, P. (2007). Le design de la recherche. In THIETART R.A. (2007), Méthode de recherche en Management, DUNOD, Paris, $560 \mathrm{p}$.

Sofarelli, D., \& Brown, D. (1998). The need for nursing leadership in uncertain times. Journal of nursing management, 6(4), 201-207. https://doi.org/10.1046/j.1365-2834.1998.00075.x 
Spinelli, R. J. (2006). The applicability of Bass's model of transformational, transactional, and laissez-faire leadership in the hospital administrative environment. Hospital topics, 84(2), 11-18. https://doi.org/10.3200/HTPS.84.2.11-19

To, M. L., Tse, H. H. M., \& Ashkanasy, N. M. (2015). A multilevel model of transformational leadership, affect, and creative process behavior in work teams. The Leadership Quarterly, 26(4), 543-556. https://doi.org/10.1016/j.leaqua.2015.05.005

Tu, Y., \& Lu, X. (2013). How ethical leadership influences employees' innovative work behavior: A perspective of intrinsic motivation. Journal of Business Ethics, 116(2), 441-455. http://dx.doi.org/10.1007/s10551-012-1455-7

Yahchouchi, G. (2009). Employees' Perceptions of Lebanese Managers' Leadership Styles and Organizational Commitment. International Journal of Leadership Studies, 4(2), 127-140. Retrieved from https://www.regent.edu/acad/global/publications/ijls/new/vol4iss2/IJLS_V4Is2_Yahchouchi.pdf

Yaktin, U. S., Azoury, N. B., \& Doumit, N. A. (2003). Personal characteristics and job satisfaction among nurses in Lebanon. The Journal of Nursing Administration, 33(7-8), 384-390. https://doi.org/10.1097/00005110-200307000-00006

Yukl, G. (2010). Leadership in organizations (7th ed.). Upper Saddle River, NJ: Prentice Hall.

Yukl, G., \& Van Fleet, D. D. (1992). Theory and research on leadership in Organizations. In Marvin D. Dunnett and Leaetta M. Hough (eds.), Handbook of Industrial and Organizational Psychology. Palo Alto, CA: Consulting Psychologist Press, 147-197.

\section{Copyrights}

Copyright for this article is retained by the author(s), with first publication rights granted to the journal.

This is an open-access article distributed under the terms and conditions of the Creative Commons Attribution license (http://creativecommons.org/licenses/by/4.0/). 